\title{
Informerte valg - viktig også for norske gravide
}

\author{
Bioteknologiloven fra 2003 har forhindret et screeningprogram for \\ Downs syndrom. Slik sett er intensjonen bak den innfridd. Men i økende \\ grad får gravide tidlig ultralydundersøkelse som «medisin», med mang- \\ lende veiledning og informasjon som konsekvens. Informerte gravide \\ er i dag et glemt tema i den politiske striden om tidlig ultralyd mellom \\ sorteringsmotstandere og nyttetilhengere.
}

\section{Berge Solberg}

berge.solberg@svt.ntnu.no

Institutt for sosialt arbeid og helsevitenskap Norges teknisk-naturvitenskapelige universitet 7491 Dragvoll

Med bioteknologiloven fra 2003 ble det trukket et skille mellom ultralydundersøkelse brukt i den alminnelige svangerskapsomsorgen og såkalt fosterdiagnostisk ultralyd (1). Politisk kan det forstås som et ønske om å skille mellom normale medisinske prosedyrer og aktiv bortvelging av fostre med sykdom og funksjonshemning. Det siste kalte man «fosterdiagnostikk», og det er bare dette som er lovregulert.

Fostermedisinere var tidlig ute med å påpeke de betydelige utfordringene dette skillet innebar (2). Verken logisk eller praktisk mente man det gikk opp og spådde at dette kom til å bli en sovende lov. Likevel inneholdt skillet mellom «fosterdiagnostisk ultralyd» og «ordinær svangerskapsomsorg» en politisk realitet: Adgangen til prenatal risikoberegning for Downs syndrom for gravide under 38 år ble stanset. Det var $i$ alle fall det mange norske politikere inntil nylig trodde.

\section{«Alle har krav på tidlig ultralyd»}

Overraskende for noen kunne helseministeren nylig slå fast at alle gravide i Norge allerede i dag har krav på tidlig ultralyd (3). Ministeren henviste til Veiledende retningslinjer for bruk av ultralyd $i$ svangerskapet, fra 2004, som åpnet for at også «uro» er en del av den medisinske indikasjonen for å få ultralydundersøkelse tidlig i graviditeten (4). Helsepersonell kan selv, i samsvar med egen kompetanse, vurdere hvor langt det er indisert å undersøke en «urolig» kvinne.

Om nå ikke alle kan sies å ha direkte «krav» på tidlig ultralyd i dag, siden det er opp til legen å avgjøre om en pasient er «urolig» eller ei, så er det nok likevel tilfellet at det for yngre gravide er lett å få denne undersøkelsen. Dette kan synes underlig, på bakgrunn av dagens politiske debatt - som nettopp handler om hvorvidt tidlig ultralyd skal bli mulig å få. Men årsaken til denne forvirringen er delvis av semantisk art.

Ultralydundersøkelse tidlig i svangerskapet er ikke nødvendigvis det samme som risikoberegning for Downs syndrom. Undersøkelsen kan gjøres tidlig uten måling av nakkefold og nesebein, og den kan selvsagt gjøres uten dobbelttest. Mente så Stortinget at urolige gravide kvinner har krav på tidlig ultralyd (risikoberegning for Downs syndrom) eller bare ultralyd tidlig? Trolig er svaret det siste. Men i praksis er det blitt det første. Etter hvert som kompetansen blant ultralydpersonell øker, blir det naturlig å «sjekke alt» for å kunne berolige en urolig kvinne. En ultralydundersøkelse på medisinsk indikasjon der indikasjonen er «uro», kan være lik den undersøkelsen en gravid kvinne på 38 år blir tilbudt under merkelappen «fosterdiagnostikk». Fagmiljøene praktiserer nok dette ulikt, men likevel hersker det liten tvil om at mange velger å tolke retningslinjene liberalt. Med helseministerens «klargjøring» er det rimelig å forvente at en enda større andel av de gravide vil få gjort risikoberegning for kromosomavvik basert på «uro». Beveger vi oss da mot det «sorteringssamfunn» kritikerne frykter?

\section{Budskap og realiteter}

I forbindelse med evalueringen av den danske nakkefoldscreeningen (5) ble det slått stort opp i norske medier at i Danmark ble antall barn født med Downs syndrom halvert etter at screeningprogrammet ble innført i 2004. «Utrydning» ble det kalt av enkelte (6). Hvor forskjellig er så Norge fra Danmark? På den ene side er det aldri blitt foretatt flere aborter ved Downs syndrom her i landet enn det er blitt gjort i de senere år (7). Siden kvinner nesten alltid velger abort ved påvist Downs syndrom, må hovedforklaringen være økt diagnostikk, ikke endring i personlige valg. Dette støttes også av fostermedisineres påstand om at majoriteten av norske gravide i dag får tidlig ultralyd (8). På den annen side er det heller aldri født flere barn med Downs syndrom enn i dag.

Forklaringen på dette paradokset - mer diagnostikk og stigende aborttall samtidig som antallet fødte barn med Downs syndrom likevel er høyt - skyldes økende alder hos de gravide. Bare en velorganisert screening med høy oppslutning, slik som i Danmark, vil kunne endre dramatisk på tallet på barn med Downs syndrom som blir født.

Frykten for «sorteringssamfunnet» har vært sterkere i norsk politikk enn i dansk, og kan i bunn og grunn forstås som en frykt for et samfunn uten Downs syndrom (9). Selv om norske gravide foreløpig ser ut til å velge likt som de danske når de får sjansen, er det på symbolplanet den etiske striden står for mange. Det er ikke «the choices made but the choices made available» som er problemet for «sorteringsmotstanderne» (10). Forskjellen mellom Danmark og Norge består primært i dette: Helsevesenets tilrettelegging for bortvalg av fostre med Downs syndrom fortolkes i større grad her i landet enn i vårt naboland i sør som en krenkende «beskjed» til mennesker med syndromet om at deres liv er oppe til vurdering. Dermed vil enhver liberalisering av norsk fosterdiagnostikk automatisk bli et politisk spørsmål.

\section{Yngre gravide faller utenfor informasjonskravet}

Om denne debatten er viktig og engasjerende, representerer den likevel bare ett av flere etiske hensyn innen fosterdiagnostikk og svangerskapsomsorg. Om vi nå setter parentes rundt «sorteringsdebatten» for en stakket stund, er det da noe problem at gravide får en ufarlig ultralydundersøkelse tidlig?

Bioteknologiloven regulerer fosterdiagnostikken med bl.a. krav til skriftlig samtykke og omfattende genetisk veiledning. Forskjellen på 38-åringen som blir tilbudt fosterdiagnostikk ut fra hennes alder og 28-åringen som sier hun er «urolig» og får tilnærmet samme undersøkelse, er at førstnevnte har et lovbestemt krav på genetisk veiledning før undersøkelsen, mens 28åringen faller utenfor alle informasjonskrav og rutiner. Det betyr at informasjon om de veivalg hun er i ferd med å gå inn på, invasive tester som kan følge i kjølvannet av nakkefoldsmålingen, forståelsen av risiko- 


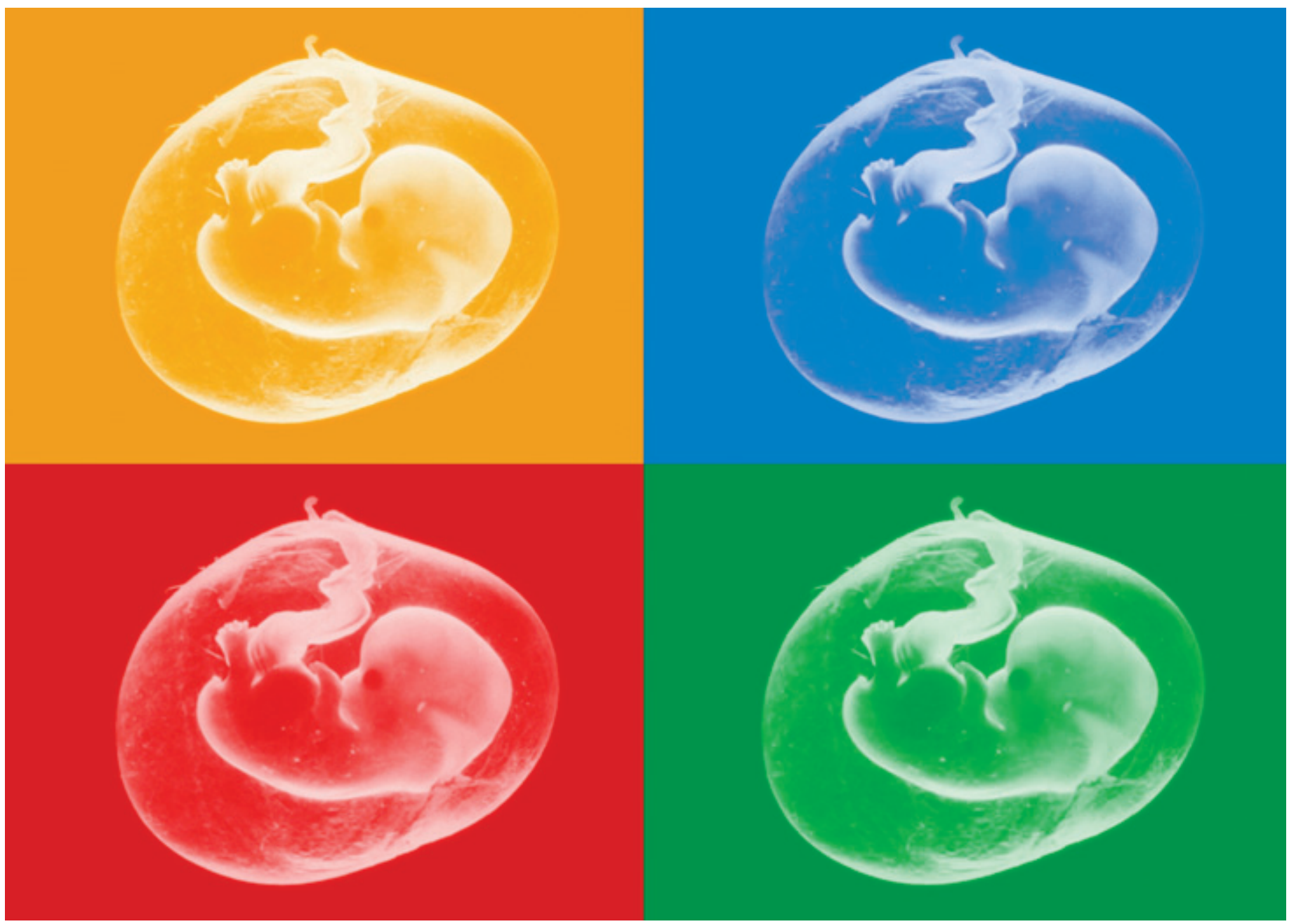

Illustrasjonsfoto Science Photo Library/GV-Press/NordicPhotos

beregning i svangerskapet, falske alarmer, falskt negative funn, grenseverdi samt informasjon om kromosomavvik og Downs syndrom i prinsippet kan være helt fraværende fra denne undersøkelsen. Forbuden frukt smaker som kjent best - kanskje for godt, siden mulige negative effekter av undersøkelsen blir utematisert.

\section{Medisinsk baserte kontra autonomibaserte unders $ø$ kelser}

Man kan selvsagt ikke utelukke at alle gravide får god informasjon i norsk helsevesen. Men det er rimelig å anta at det ikke skjer. Vektlegging av samtykke, informasjon og autonomi tar seg nemlig vesensforskjellig ut avhengig av om en undersøkelse er medisinsk basert eller autonomibasert. Fra et etisk synspunkt er det også rimelig å hevde at kravet til informasjon og veiledning er betydelig større der tester og undersøkelser tilbys av respekt for en persons autonomi enn der hvor de tilbys av medisinske grunner. En test som tilbys av respekt for en gravid kvinnes autonomi vil nemlig feile i sin intensjon dersom den gravide ikke aner rekkevidden av sine valg. En test som tilbys av medisinske grunner vil lykkes i sin intensjon uavhengig av om den gravide er godt informert om alle aspekter ved testen.

En kvinne som har en blødning tidlig i svangerskapet, behøver eksempelvis ikke veiledning eller informasjonsbrosjyrer om alt ultralydundersøkelsen kan innebære. Det ligger i kortene at kvinnen trenger den av medisinske grunner. Eventuelle negative konsekvenser av undersøkelsen blir bieffekter av en udelt positiv intensjon. Ultralyd på medisinsk indikasjon gir seg derfor selv.

Å velge barn, derimot, handler ikke primært om medisin, snarere om selvbestemmelse og autonomi. Informasjon og veiledning er nødvendige faktorer for å sikre at det kan gjøres autonome valg. I bioteknologiloven forsøkte man nettopp å trekke opp et skille mellom medisinsk baserte og autonomibaserte unders $\varnothing$ kelser. Men da «uro» i Norge ble en medisinsk indikasjon på linje med blødning i svangerskapet, tok man egentlig det viktigste motivet bak ethvert ønske om fosterdiagnostikk og puttet det inn i den normale svangerskapsomsorgen. Konsekvensen ble åpen adgang til risikoberegning for kromosomavvik under merkelappen «medisin», uten etablerte rutiner for forhåndsveiledning og informasjon.

\section{Informert samtykke}

Ultralydteknologien er spesiell ved at den innbyr til sammenblanding av en medisinsk og en autonomibasert begrunnelse. Teknologien lar seg ikke lett bringe på politisk formel. Den beste og enkleste løsningen kunne nok være å tilby tidlig ultralyd til alle som rutine ut fra en medisinsk begrunnelse. Da slapp man omfattende informasjonsog veiledningsrutiner, siden undersøkelsen var medisinsk motivert, og man unngikk en stigmatiserende brodd ved at tilbudet primært handlet om medisin og ikke om Downs syndrom.

Problemet er imidlertid at den medisinske begrunnelsen ser ut til å mangle. I Kunnskapssenterets rapport fra 2008 ble det konkludert med at den medisinske nytten av tidlig ultralydundersøkelse ikke kunne dokumenteres (11). Selvsagt gir tidlig ultralyd informasjon om betydelig mer enn risikoen for kromosomavvik. Og mange gravide (og deres menn) vil ønske å se sitt barn på skjermen så tidlig som mulig. Men hvor stor medisinsk effekt en undersøkelse har, er en ekspertvurdering. Inntil Kunnskapssenterets konklusjoner er tilbakevist, synes det å være vanskelig å hoppe bukk over dem. Det er heller ikke 
til å komme vekk fra at den viktigste grunnen til at en rekke land i Europa har innført tidlig ultralydscreening, har vært undersøkelsens styrke i å oppdage kromosomavvik.

Arbeiderpartiet ønsker nå å tilby tidlig ultralydundersøkelse til alle gravide med henvisning til medisinsk nytte. Samtidig ønsker opposisjonen ingen endring av bioteknologiloven - for å unngå «sorteringssamfunnet». I begge disse politiske posisjonene blir informasjons- og veiledningsaspektet skadelidende. I den første ved at risikoberegning for kromosomavvik blir tåkelagt bak antatt nytte for fosteret og dermed fremstilles som et nødvendig gode. I den andre ved at dagens bioteknologilov slipper de gravide inn bakdøren til risikoberegning og man dermed kan hoppe bukk over informasjonskravet i fosterdiagnostikken.

Kombinert ultralyd og blodprøve er per i dag, i mangel av påvist medisinsk gevinst, en type undersøkelse som den gravide kan klare seg uten dersom hun ikke ønsker å få fastsatt risiko for kromosomavvik. Undersøkelsen vil unødvendig uroe en rekke gravide med falske alarmer, og noen vil miste sitt ønskede barn i den videre letingen etter et foster med Downs syndrom (12). Informasjonsutfordringene er store ved en slik undersøkelse, og det er dokumentert at kvinner synes det er vanskelig å forstå hva nakkeoppklaring og myke markører er (11). Det bør fremtre klart for gravide hva som er styrken ved denne undersøkelsen - at det primært handler om å gi henne valgmuligheter når det gjelder graviditeten og hennes fremtid, det handler ikke om barnets beste. Informert samtykke vil ellers være en illusjon.

\section{Fremtidens testsamfunn}

Selv om ultralyd er blitt et politisk tema i Norge, så er «sorteringsdebatten" ikke lenket til noen bestemt teknologi. Det er nå utviklet og patentert en ikke-invasiv diagnostisk test for Downs syndrom, basert på føtalt DNA i mors blod (13). Teknologiutviklingen åpner derfor for et scenario der alle gravide i prinsippet kan ta en diagnostisk test for Downs syndrom, ikke bare en screeningtest, som kombinert ultralydundersøkelse og blodprøve.

Informerte og reflekterte gravide vil trolig være den beste medisin for å sikre både gode svangerskap og ansvarlige bortvalg av barn stilt overfor morgendagens testsamfunn. Men skal informerte valg spille en rolle, trenger de gravide både kvalitetssikret informasjon og klare budskap om formålet med og verdien av ulike typer undersøkelser. Dagens politiske ultralydstrid mellom sorteringsmotstandere og nyttetilhengere synes å underkommunisere at en av de største utfordringene i fosterdiagnostikken fremover handler om informerte valg.

Oppgitte interessekonflikter: Ingen

\section{Litteratur}

1. Lov om humanmedisinsk bruk av bioteknologi m.m. (bioteknologiloven). www.lovdata.no/all nl-20031205-100.html (4.4.2009).

2. Salvesen KÅ. Ultrauklar bioteknologilov. Tidsskr Nor Lægeforen 2004; 124: 819-21.
3. Schjerve VA. - Alle har KRAV på tidlig ultralyd. Dagbladet 28.1.2009.

4. Veiledende retningslinjer for bruk av ultralyd i svangerskapet. Bruk av ultralyd i den alminnelige svangerskapsomsorgen og i forbindelse med fosterdiagnostikk. Rundskriv, IS-23/2004. Oslo: Sosial og helsedirektoratet, 2004. www.helsedirektoratet.no/vp/multimedia/archive/00001/IS232004 1180a.doc (26.4.2009).

5. Ekelund CK, Jørgensen FS, Petersen OB et al. Impact of a new national screening policy for Down's syndrome in Denmark: population based cohort study. BMJ 2008; 337: a2547.

6. Weisser A. KrF kaller dansk praksis for utrydding. Adresseavisen 27.1.2009. www.adressa.no/nyheter/innenriks/article1234751.ece (26.4.2009).

7. Mo E, Seliussen I, Irgens LM et al. Rapport 2005 om nemndbehandlede svangerskapsavbrudd. Medisinsk fødselsregister. www.fhi.no/dav/ 0a51ecd6ea.doc (26.4.2009)

8. Akerø M. Gravide bør få tidligere ultralyd. TV2nyheter 2.2.2009. www.tv2.no/gmn/nettprat/ article2539218.ece (26.4.2009).

9. Solberg B. Frykten for et samfunn uten Downs syndrom. Etikk i praksis 2008; 2: 33-52.

10. Press N. Assessing the expressive character of prenatal testing: the choices made or the choices made available? I: Parens E, Asch A, red. Prenata testing and disability rights. Washington D.C.: Georgetown University Press, 2000: 214-34.

11. Reinar LM, Smedslund G, Fretheim A et al. Rutinemessig ultralydundersøkelse i svangerskapet. Rapport nr 11/2008 Oslo: Kunnskapssenteret, 2008. www.kunnskapssenteret.no/Publikasjoner/ 2759.cms (26.4.2009)

12. Getz L, Kirkengen AL. Ultrasound screening of pregnancy: advancing technology, soft markers of fetal anomaly and unacknowledged ethical dilemmas. Soc Sci Med 2003; 56: 2045-57.

13. Wright C. Cell-free fetal nucleic acids for noninvasive prenatal diagnosis. Report of the UK expert working group. PHG-foundation 2009. www.phgfoundation.org (26.4.2009).

Manuskriptet ble mottatt 25.3. 2009 og godkjent 30.4. 2009. Medisinsk redaktør Anne Kveim Lie. 